\title{
PAPER
}

\section{Intrathecal inflammation precedes development of Alzheimer's disease}

\author{
E Tarkowski, N Andreasen, A Tarkowski, K Blennow
}

J Neurol Neurosurg Psychiatry 2003;74:1200-1205

See end of article for authors' affiliations

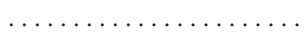

Correspondence to: Dr E Tarkowski,

Department of

Rheumatology,

Guldhedsgatan 10, S-413

46 Göteborg, Sweden:

elisabeth.tarkowski

@immuno.gu.se

Received 26 June 2002

In final revised form

18 March 2003

Accepted 1 April 2003

\begin{abstract}
Objectives: To analyse the cerebrospinal fluid (CSF) values of the proinflammatory cytokines, interleukin $1 \beta$ (IL 1 $\beta)$, tumour necrosis factor $\alpha$ (TNF $\alpha), G M-C S F$, of the anti-inflammatory cytokine TGF $\beta$, of tau protein, a marker for neurodegeneration, and of $\beta$ amyloid $(A \beta)$, a protein involved in the formation of senile plaques, in prospectively followed up patients with mild cognitive impairment (MCI).

Methods: Analyses of CSF levels of TNF $\alpha$, IL $1 \beta$, GM-CSF, TGF $\beta, \beta a$, and tau protein were performed using ELISA in 56 patients with $\mathrm{MCl}$ who were followed up prospectively and in 25 age matched, healthy controls.

Results: Patients with $\mathrm{MCl}$ displayed significantly higher levels of TNF $\alpha$ and tau protein and significantly lower levels of TGF $\beta$ and A $\beta$ compared with the healthy controls. After nine months of follow up, 25 patients still displayed $\mathrm{MCl}$ while the remaining 31 patients had progressed to Alzheimer's disease (AD). Only $\mathrm{MCl}$ patients who progressed to $A D$ at follow up, showed significantly higher CSF levels of TNF $\alpha$ than controls. In addition, reduced CSF-A $\beta 42$ levels were only found in $\mathrm{MCl}$ patients that progressed to $A D$, further supporting the notion that disturbed metabolism of $A \beta$ is an early finding in AD.

Conclusions: These results demonstrate increased production of the proinflammatory cytokine, TNF $\alpha$ and decreased production of the anti-inflammatory cytokine TGF $\beta$ in patients with $\mathrm{MCl}$ at risk to develop $A D$, suggesting a propensity towards inflammation in this patient group and indicating that CNS inflammation is a early hallmark in the pathogenesis of $A D$.
\end{abstract}

A lzheimer's disease (AD) is characterised by atrophy of the brain subsequent to neuronal and synaptic degeneration, decreased dendritic arborisation, as well as formation of neurofibrillary tangles and senile plaques (SP). A protein of 40-42 amino acid length, with a high tendency to aggregate, called $\beta$ amyloid protein $(A \beta)$, has been identified as the major component of the SP. ${ }^{1} \mathrm{~A} \beta$ is derived from a $90-140$ $\mathrm{kDa}$ precursor, called amyloid precursor protein (APP). ${ }^{2}$

The cause of $\mathrm{AD}$ and reasons for its progressive course are still unknown but involvement of the immune system in the pathogenesis has been discussed for years. For example, $\mathrm{CD}^{+}$ and $\mathrm{CD}^{+} \mathrm{T}$ lymphocytes are present in affected $\mathrm{AD}$ brain tissue. ${ }^{3}$ In addition, reactive microglial cells have been demonstrated to express class-II molecules of the major histocompatibility complex (MHC) and Fc receptors. ${ }^{4}$ Thus, all the appropriate elements necessary for an immune response are present locally in brains of $\mathrm{AD}$ patients.

Both activated microglia and T lymphocytes can be a source of cytokine production. ${ }^{5}$ Indeed, interleukin (IL) 1, IL6, and tumour necrosis factor (TNF) $\alpha$ are detected in brains of $\mathrm{AD}$ patients. ${ }^{6-8}$ These cytokines may be involved in the pathogenesis of $\mathrm{AD}$, for example, by promoting local inflammatory responses. ${ }^{9}$ ILl has also been demonstrated to increase the synthesis of APP mRNA in human endothelial cells, ${ }^{10}$ suggesting a direct role for this cytokine in the formation of SP. Interestingly, the ILl receptor antagonist (ILlra) naturally occurring in the brain, ${ }^{11}$ and blocking interaction of ILl with its receptor, ${ }^{12}$ displays neuroprotective properties with respect to ischaemic and excitotoxic brain damage in experimental rat models. ${ }^{13}$ Furthermore, TNF $\alpha$, a powerful cytokine inducing apoptosis in the extraneural compartments of the body, has been demonstrated to protect rat hippocampal, septal and cortical cells against metabolic-excitotoxic insults ${ }^{14}$ and to facilitate regeneration of injured axons. ${ }^{15}$ More importantly, TNF $\alpha$ and TNF $\beta$ protect neurons against $A \beta$ triggered toxicity. ${ }^{16}$

We have previously demonstrated increased levels of the proinflammatory cytokines, TNF $\alpha, \mathrm{GM}-\mathrm{CSF}$ and of the anti-inflammatory cytokine TGF $\beta$ levels in the cerebrospinal fluid (CSF) of patients with established AD. ${ }^{17-20}$ Thus, a body of evidence suggests an increased cytokine production in the brain of $\mathrm{AD}$ patients and the potential involvement of these cytokines in the pathophysiology of AD. However, it is not known whether the cytokine production is a late event in $\mathrm{AD}$, if it is an early step in the pathogenesis of $\mathrm{AD}$, or if it even precedes the diagnosis of $\mathrm{AD}$. If the last alternative would occur, the idea of inflammatory component in the pathophysiology of $\mathrm{AD}$ would be further strengthened.

The aim of this study was to analyse (1) the CSF levels of the proinflammatory cytokines, ILI $\beta, \mathrm{TNF} \alpha$, GM-CSF, and of the anti-inflammatory cytokine TGF $\beta$ in patients with mild cognitive deficit (MCI) known to proceed with time to full blown AD.

\section{METHODS}

\section{Patients}

Fifty six patients with MCI, 28 men and 28 women, 51-90 years of age (mean (SEM) 74 ( 1 ) years), all patients at the Neuropsychiatric Department, Piteå River Valley Hospital, Piteå, Sweden, were consecutively incorporated into the study during a four year period. The patients underwent a thorough clinical examination including medical history, physical, neurological and psychiatric status, psychological tests, laboratory screening tests, ECG, chest radiographs, EEG, and CT scans of the brain. All patients underwent a comprehensive

Abbreviations: AD, Alzheimer's disease; CSF, cerebrospinal fluid; IL, interleukin; TNF, tumour necrosis factor; ILI ra, ILI receptor agonist; $A \beta, \beta$ amyloid protein; MMSE, mini-mental state examination; $\mathrm{MCl}$, mild cognitive impairment; ELISA, enzyme linked immunosorbent assay; SP, senile plaque; APP, amyloid precursor protein; VEGF, vascular endothelial growth factor 
neuropsychological assessment, and a detailed evaluation of the instrumental ADL status including non-memory symptoms of dementia by an occupational therapist, as described previously in detail. ${ }^{21-23}$ We also interviewed the closest relatives for history of cognitive, occupational, and social impairment. The clinical symptomatology was evaluated, and the following symptoms recorded as absent or present: memory disturbances, dysphasia, dyspraxia, visuospatial disturbances, and personality change. The mini-mental state examination (MMSE) was used to evaluate the degree of intellectual impairment. ${ }^{24}$ The initial MMSE score was (mean (SEM)) $28.6(0.2)$ in all the patients.

All the patients were followed up prospectively and examined about nine months later (range 2-36 months). Twenty five patients still displayed a mild memory disturbances only, while the remaining 31 patients had developed additional cognitive symptoms, either evident from the medical history or the clinical examination, and had thus progressed to $\mathrm{AD}$ with dementia. The MMSE, which was only used for grading of cognitive symptoms, and not for evaluation of conversion to $\mathrm{AD}$, was significantly lower in the group that had progressed to AD (27.1 (0.4), range 22-30) than in the group that did not progress (28.6 (0.3), range 25-30).

Mild cognitive impairment was diagnosed in patients with no other cognitive symptoms than memory impairment, following the guidelines by Peterson and colleagues. ${ }^{25}$ Memory impairment was verified by neuropsychological testing. No patient had impairment of activities of the daily living, or fulfilled the DMS-IV criteria ${ }^{26}$ for dementia. An inclusion criterion was also a MMSE score at baseline of 27 or above.

$\mathrm{AD}$ was defined as dementia with predominant instrumental deficits, as well as loss of memory, but without clinical evidence of frontal lobe dementia, dementia of Lewy body type, or cerebrovascular changes such as white matter lesions. ${ }^{27}$ All patients that had progressed at follow up fulfilled the NINCDS-ADRDA criteria for probable $\mathrm{AD} .^{28} \mathrm{AD}$ had an early onset (before the age of 65 years) in nine patients and a late onset (after 65 years) in 22 patients.

For control purposes, CSF samples from 25 healthy controls, 50-83 years of age (mean (SEM) 68 (1)), without any neurological diseases or deficit, were obtained to establish normal levels of cytokines.

No patients or controls displayed symptoms or signs (for example, fever) of inflammatory or infectious conditions. In addition, all of them had erythrocyte sedimentation rate (ESR) within reference values. Patients with malignant diseases were excluded from all the study groups.

In both the MCI and the control group, CSF samples were obtained by lumbar puncture in the L3/L4 or L4/L5 interspace at the admission of the patients to the study. The first $12 \mathrm{ml}$ of CSF was collected in plastic (polypropylene) tubes, to avoid possible absorbance of proteins to the tube walls. ${ }^{21}$ All CSF samples were gently mixed to avoid possible gradient effects. No CSF sample contained more than 500 erythrocytes per $\mu$. The CSF samples were centrifuged at $2000 \times g$ for 10 minutes to eliminate cells and other insoluble material and were then immediately frozen, and stored at $-80^{\circ} \mathrm{C}$ pending biochemical analyses, without being thawed and re-frozen. The CSF and serum samples of the patients were obtained for routine analyses, protein electrophoresis, cytology, and analyses of TNF $\alpha$, ILl $\beta$, GM-CSF, TGF $\beta$, A $\beta$, and tau protein.

This study was approved by the ethics committees of the Universities of Göteborg and Umeå

\section{Reagents and procedures} Cytokine analysis

Levels of GM-CSF in CSF samples were quantified by an enzyme linked immunosorbent assay (ELISA) using GM-CSF specific monoclonal unlabelled antibodies (Pharmingen, San Diego, CA) for coating $(2 \mu \mathrm{g} / \mathrm{ml})$ of polystyrene flat bottom plates $\left(4^{\circ} \mathrm{C}\right.$, overnight), followed by washing with TRIS $0.05 \%$ Tween-20 and blocking with $1 \%$ BSA in TRIS-NaCl for one hour at $37^{\circ} \mathrm{C}$. After emptying, the plates were incubated for two hours at $37^{\circ} \mathrm{C}$ with CSF samples diluted 1:5 in TRIS-NaCl containing 1\% BSA. Biotinylated GM-CSF specific monoclonal antibodies (Pharmingen) were added and incubated overnight at $4^{\circ} \mathrm{C}$. The plates were washed again and incubated with ExtrAvidin alkaline phosphatase (Sigma, St Louis, MO). The enzyme substrate was then added, and optical density was determined in a Titertek Multiscan Photometer (Flow Laboratories, McLean, VA) at $405 \mathrm{~nm}$. The concentration of GM-CSF was calculated using a standard curve based on known quantities of human recombinant GM-CSF (Quantikine R\&D Systems, Minneapolis, MD).

Levels of IL1 $\beta$, TNF $\alpha$, and TGF $\beta$ in cerebrospinal fluid samples were estimated by ELISA (Quantikine R\&D Systems, Minneapolis, MD).

The detection level for TNF $\alpha$, ILI $\beta$, GM-CSF, and TGF $\beta$ were $0.2 \mathrm{pg} / \mathrm{ml}, 0.1 \mathrm{pg} / \mathrm{ml}, 0.04 \mathrm{ng} / \mathrm{ml}$, and $7 \mathrm{pg} / \mathrm{ml}$, respectively. All values below the detection levels were considered to be negative.

\section{Analysis of tau protein}

Tau protein levels in CSF were determined using a sandwich ELISA, constructed to measure the level of total tau, containing both phosphorylated and non-phosphorylated protein, as described previously in detail. ${ }^{29}$

\section{Analysis of $\beta$ amyloid protein}

CSF-A 342 was determined using a sandwich ELISA (INNOTEST $\beta$ amyloid(1-42), Innogenetics, Ghent, Belgium) constructed to specifically measure $\beta$ amyloidl-42, as previously described. ${ }^{2630}$

\section{Statistics}

Statistical analysis regarding the differences between means was carried out by the Mann-Whitney U test. Paired data were analyded with Wilcoxon's signed rank test. A $\chi^{2}$ test was used to analyse categorical data. Spearman's rank order correlation method was used to calculate correlations and the level of significance of the correlations.

In addition to the non-parametric approach, the data concerning the CSF levels of TNF $\alpha$, TGF $\beta$, ILI $\beta$, tau, and A $\beta$ were transformed to normalise the distribution and thereby permit use of parametric techniques. For the logaritmic transformation, all values for TNF $\alpha$ and ILl $\beta$ below the detection levels were considered to be at the detection level. A two way analysis of variance with sex and age as factors and CSF-TNF $\alpha$, CSF-TGF $\beta$, CSF-tau; CSF-A $\beta$ as effect variables was performed. Sex and age did not contribute to the variance in any of the tests performed and could be excluded from further analyses. Unpaired Student's $t$ test was then used to compare the different groups as shown in the table 3. A p value $<0.05$ was considered statistically significant.

To assess the propensity to inflammatory reaction in the CNS, the ratio between TNF $\alpha$ and TGF $\beta$ level was calculated in each patient as follows: CSF levels of TNF $\alpha(\mathrm{pg} / \mathrm{ml})$ divided by CSF levels of TGF $\beta(\mathrm{pg} / \mathrm{ml})$, multiplied by 1000 . The values below detection levels were set to 0.01 .

\section{RESULTS}

Patients

Table 1 shows the clinical features of the patients. The patients who progressed to $\mathrm{AD}$ at the follow up nine months later were slightly but significantly $(\mathrm{p}=0.03)$ older than patients who did not. As expected, the patients who progressed to AD displayed significantly higher $(p=0.007)$ degree of cognitive impairment at the follow up than patients who did not. Also, patients with $\mathrm{AD}$ at the follow up showed a significant decrease 
Table 1 Clinical features of $\mathrm{MCl}$ patients included in the study

\begin{tabular}{llll}
\hline Clinical features & $\begin{array}{l}\text { All patients } \\
(n=56)\end{array}$ & $\begin{array}{l}\text { Patients with } \mathrm{AD} \text { at } \\
\text { follow up }(\mathrm{n}=31)\end{array}$ & $\begin{array}{l}\text { Patients with } \mathrm{MCl} \text { at } \\
\text { follow up }(\mathrm{n}=25)\end{array}$ \\
\hline Age & $72(1)$ & $74(1)$ & $69(2)$ \\
Initial MMSE & $28.9(0.1)$ & $28.8(0.2)$ & $29.0(0.2)$ \\
MMSE at follow up & $27.8(0.2)$ & $27.1(0.4)^{* * *}$ & $28.6(0.3)$ \\
MMSE change & $-1.1(0.3)$ & $-1.7(0.4)$ & $-0.4(0.3)$ \\
\hline \multirow{2}{*}{${ }^{* *} \mathrm{p}<0.001$ in comparison with initial MMSE. }
\end{tabular}

Table 2 CSF levels of TNF $\alpha$, TGF $\beta$, IL1 $\beta$, GM-CSF, tau, and A $\beta$ in prospectively followed up $\mathrm{MCl}$ patients

\begin{tabular}{lllll}
\hline & All patients & $\begin{array}{l}\text { Patients with } \mathrm{AD} \text { at } \\
\text { follow up }\end{array}$ & $\begin{array}{l}\text { Patients with } \mathrm{MCl} \text { at } \\
\text { follow up }\end{array}$ & Healthy controls \\
\cline { 2 - 5 } & $(\mathrm{n}=56)$ & $(\mathrm{n}=31)$ & $(\mathrm{n}=25)$ & $(\mathrm{n}=25)$ \\
\hline TNF $\alpha$ & $0.4(0.1)^{* * *}$ & $0.4(0.1)^{* * *}$ & $0.4(0.1)^{* *}$ & $0.2(0.1)$ \\
TGF $\beta$ & $0.3(0.5)$ & $0.3(0.1)$ & $0.3(0.4)$ & $0.0(0.0)$ \\
& $124(20)^{* * *}$ & $104(6)^{* * *}$ & $149(43)^{* * *}$ & $159(10)$ \\
ILI $\beta$ & $99(53)$ & $99(46)$ & $94(63)$ & $150(61)$ \\
& $0.04(0.02)$ & $0.04(0.02)$ & $0.05(0.04)$ & $0.0(0.0)$ \\
GM-CSF & $0.0(0.0)$ & $0.0(0.0)$ & $0.0(0.0)$ & $0.0(0.0)$ \\
& $0.0(0.0)$ & $0.0(0.0)$ & $0.0(0.0)$ & $18.0(9.0)$ \\
Tau & $0.0(0.0)$ & $0.0(0.0)$ & $0.0(0.0)$ & $0.0(40.0)$ \\
& $600(29)^{* * *}$ & $628(29)^{* * *}$ & $564(53)^{* *}$ & $314(36)$ \\
A $\beta$ & $568(313)$ & $588(281)$ & $476(382)$ & $299(196)$ \\
& $683(42)^{* *}$ & $602(43)^{* * *}$ & $784(72)$ & $931(55)$ \\
& $557(410)$ & $555(167)$ & $698(600)$ & $940(219)$ \\
\hline
\end{tabular}

All data are presented as mean (SEM) (first row for each parameter) and median (interquartile range) (second row for each parameter) and are expressed in $\mathrm{pg} / \mathrm{ml}$ for TNF $\alpha, \mathrm{IL} \beta, \mathrm{TGF} \beta$, and $\mathrm{A} \beta, \mu / \mathrm{ml}$ for tau, and in $\mathrm{ng} / \mathrm{ml}$ for GM-CSF. ${ }^{* * *} \mathrm{p}<0.001$ in comparison with controls. ${ }^{* *} \mathrm{p}<0.01$ in comparison with controls.

$(\mathrm{p}=0.0004)$ of cognitive impairment compared with their initial degree of impairment, whereas the remaining subjects did not show a similar trend.

\section{Intrathecal TNF $\alpha$ levels}

Forty one of 56 patients but only 7 of 33 controls had detectable levels of TNF $\alpha$ in CSF $(\mathrm{p}<0.0001)$. As table 2 shows, the levels of TNF $\alpha$ in the CSF were significantly increased $(\mathrm{p}=0.0009)$ in patients with MCI (mean (SEM) $0.4(0.1)$ $\mathrm{pg} / \mathrm{ml})$ compared with the controls $(0.2(0.1) \mathrm{pg} / \mathrm{ml})$. After logaritmic transformation of the data, the differences between the groups remained significant (table 3 ). In addition, when the TNF $\alpha$ levels of the patients who developed AD at the follow up and of the patients who did not were analysed separately, only MCI patients who progressed to $\mathrm{AD}$ at follow up, showed significantly higher CSF levels of TNF $\alpha$ compared with controls (table 3). The TNF $\alpha$ levels in CSF did not correlate to any of the clinical features including age of the patients $(r=-0.05$, NS), initial MMSE score $(r=0.04, \mathrm{NS})$, or MMSE score at the follow up $(r=0.03$, NS).

\section{Intrathecal IL1 $\beta$ and GM-CSF levels}

Six of 56 patients but none of 33 controls had detectable levels of ILl $\beta(p<0.05)$. The CSF levels of ILl $\beta$ did not differ signifi- cantly between patients and controls (table 2 and table 3 ). However, the ILI $\beta$ levels were significantly correlated both to MMSE at the first examination $(r=0.46 ; \mathrm{p}=0.0006)$ and at the follow up $(r=0.34 ; \mathrm{p}=0.001)$ as well as to the change in MMSE between the two examinations $(r=0.30 ; \mathrm{p}=0.03)$ and to the age of the patients $(r=0.32 ; \mathrm{p}=0.02)$.

None of the patients and four of the controls displayed detectable GM-CSF levels in CSF (NS). The CSF levels of GM-CSF did not differ significantly between patients and controls (table 2).

\section{Intrathecal TGF $\beta$ levels}

All the patients and all the controls displayed detectable levels of TGF $\beta$ in the CSF (NS). The levels of TGF $\beta$ in the CSF were significantly decreased $(\mathrm{p}=0.0001)$ in patients with MCI (mean (SEM) $124(20) \mathrm{pg} / \mathrm{ml}$ ) compared with the controls (159 (10) pg/ml) (table 2 and table 3). When the TGF $\beta$ levels of the patients who developed $\mathrm{AD}$ at the follow up and of the patients who did not were analysed separately, both groups displayed significantly decreased and similar TGF $\beta$ levels compared with the controls (table 2 and table 3 ). To assess the propensity to inflammation in the people studied, the ratio between TNF $\alpha$ and TGF $\beta$ was calculated as described in

Table 3 Significance levels between the patient groups and controls as well as between patients who converted to $A D$ at the follow up and patients who did not

\begin{tabular}{|c|c|c|c|c|c|}
\hline & \multicolumn{5}{|c|}{ Significance levels } \\
\hline & TNF $\alpha$ & TGF $\beta$ & ILI $\beta$ & $\mathrm{A} \beta 42$ & Tau \\
\hline All patients $v$ controls & 0.046 & 0.002 & NS & 0.003 & 0.0001 \\
\hline$A D \vee M C l$ at follow up & NS & NS & NS & 0.042 & NS \\
\hline $\mathrm{MCl}$ at follow up $v$ controls & NS & 0.05 & NS & NS & 0.003 \\
\hline$A D$ at follow up $v$ controls & 0.039 & 0.0004 & NS & 0.0001 & 0.0001 \\
\hline
\end{tabular}




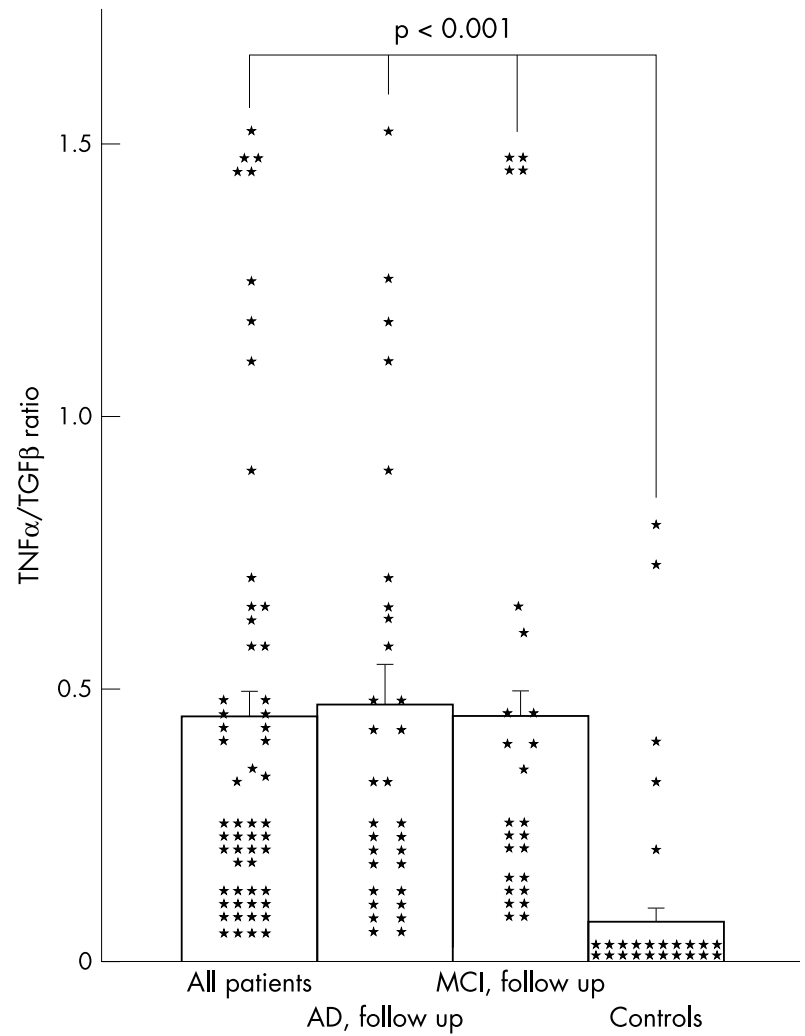

Figure 1 Ratio between CSF levels of TNF $\alpha$ and TGF $\beta$ in 56 patients with $\mathrm{MCl}, 31$ patients who develop $\mathrm{AD}$ at the follow up, 25 patients with remaining $\mathrm{MCl}$ at the follow up, and in 27 healthy controls (mean (SEM)). The ratio was calculated as described in Methods. High ratio indicates increased propensity to inflammation because of increased TNF $\alpha$ levels and decreased TGF $\beta$ levels as compared with the healthy controls. ${ }^{* * *} p<0.0001$.

Methods. All the patient groups studied displayed significantly higher TNF $\alpha$ to TGF $\beta$ ratios than healthy controls (fig 1), indicating a significantly higher proinflammatory state in the patients at risk to develop AD.

The TGF $\beta$ levels in CSF did not correlate to any of the clinical features including age of the patients $(r=0.2$; NS), initial degree of intellectual impairment $(r=-0.03, \mathrm{NS})$ or degree of intellectual impairment at the follow up $(r=-0.03$, NS).

\section{Intrathecal tau levels}

All the patients and all the controls displayed detectable levels of tau in the CSF (NS). The CSF levels of tau were significantly higher $(\mathrm{p}=0.009)$ in patients with MCI, and both in the group who developed $\mathrm{AD}$ at the follow up $(p=0.0001)$ and in patients with remaining MCI $(p=0.01)$, compared with the healthy controls (table 2 and table 3 ). The intrathecal tau levels did not differ significantly between patients with $\mathrm{AD}$ and patients with MCI at the follow up (table 3). The intrathecal levels of tau were not correlated to the age of the patients $(r=-0.16$, NS). In addition, the intrathecal levels of tau protein were not correlated either to the initial degree of intellectual impairment ( $r=-0.014, \mathrm{NS})$, or to the degree of intellectual impairment at the follow up ( $r=-0.23$; NS). However, when the patients who progressed to $\mathrm{AD}$ and the patients who did not were analysed separately, the levels of tau were significantly correlated to the MMSE levels at the follow up only in patients with $\mathrm{AD}(r=-0.41 ; \mathrm{p}=0.02)$, but not in patients with remaining MCI $(r=0.023$; NS).

The levels of tau were correlated $(r=0.42 ; \mathrm{p}=0.002)$ to the levels of IL1 $\beta$ in all patients with MCI. Interestingly, when analysed separately, the levels of tau were significantly correlated to the levels of ILI $\beta$, only in patients who developed AD at the follow up $(r=0.45 ; \mathrm{p}=0.01)$ but not in patients with remaining MCI $(r=0.37$; NS). The levels of tau were not significantly correlated to the levels of the other cytokines in any of the groups studied.

Intrathecal levels of $\mathbf{A} \beta \mathbf{4 2}$

All the patients and all the controls displayed detectable levels of $A \beta 42$ in the CSF (NS). The CSF levels of $A \beta 42$ were significantly lower $(\mathrm{p}=0.004)$ in all patients with MCI, compared with the healthy controls (table 2 and table 3 ). Subsequent analysis revealed that only patients who developed $\mathrm{AD}$ at the follow up displayed significantly lower A $\beta 42$ than controls whereas patients with remaining MCI did not (table 2 and table 3). The intrathecal levels of $A \beta 42$ were not correlated to the age of the patients $(r=-0.03$, NS). In addition, the intrathecal levels of $A \beta 42$ were not correlated either to the initial degree of intellectual impairment $(r=0.007$, NS), or to the degree of intellectual impairment at the follow up $(r=0.18$; NS).

The levels of $\mathrm{A} \beta 42$ were not correlated ( $r=0.24$; NS) to the levels of IL1 $\beta$ in all patients with MCI. However, upon subsequent analysis, the levels of $A \beta 42$ were significantly correlated to the levels of ILI $\beta$, only in patients who developed AD at the follow up $(r=0.37 ; \mathrm{p}=0.04)$ but not in patients with remaining MCI ( $r=0.09$; NS). The levels of A 342 were not significantly correlated to the levels of the other cytokines in any of the groups studied.

\section{DISCUSSION}

Our study has shown increased levels of the proinflammatory cytokine TNF $\alpha$ and decreased levels of the anti-inflammatory cytokine TGF $\beta$ in the CSF of patients with MCI compared with healthy controls. Patients with MCI also displayed higher levels of tau, a marker for neurodegeneration, and lower levels of $\mathrm{A} \beta 42$, a protein involved in the formation of senile plaque in $\mathrm{AD}$ brain. In addition, the levels of IL1 $\beta$, a proinflammatory cytokine involved in neurotoxicity and in the production of APP, the precursor molecule to A $\beta 42$, were significantly correlated to the levels of tau and of $A \beta$ in patients with MCI who progressed to full blown $\mathrm{AD}$ at the follow up nine months later

An increasing body of evidence suggests that inflammation in CNS, mediated by glial activation and production of inflammatory mediators such as cytokines and complement, plays a part for pathophysiology of $\mathrm{AD} .^{31}$ In this respect, we have previously demonstrated intrathecal production of TNF $\alpha$ in patients with $\mathrm{AD} .{ }^{17}{ }^{18}$ This study suggests that the intrathecal production of TNF $\alpha$ may be not only viewed as an early hallmark of $\mathrm{AD}$ but may actually precede clinically manifest AD. This finding is important because it indicates that cytokine release is not a late consequence of the disease but rather might be one of the initiating factors.

In addition, when the normalised TNF $\alpha$ levels of the patients who developed $\mathrm{AD}$ at the follow up and of the patients who did not were analysed separately, only MCI patients who progressed to $\mathrm{AD}$ at follow up, showed significantly higher CSF levels of TNF $\alpha$ than the controls, suggesting an involvement of this cytokine in the progression of dementia. However, we did not find any significant differences regarding the initial TNF $\alpha$ mean levels between patients who proceeded to overt $\mathrm{AD}$ and patients who did not at the follow up, nine months later. One possible explanation is that the observation period is too short and that most patients would convert to $\mathrm{AD}$ later on. The lack of significant difference between the groups of patients with MCI who progressed to $\mathrm{AD}$ and those who do not may also be attributable to the small sample size of the subgroups. Another possibility is that a second event is required for development of $\mathrm{AD}$ in MCI patients. Such an event could be additional production of cytokines regulating amyloidogenesis. Interestingly, we have previously 
demonstrated that patients with overt, established $\mathrm{AD}$ displayed high intrathecal levels of TGF $\beta^{20}$ whereas, in the present study, that patients with MCI displayed significantly decreased levels of this cytokine. Combined, these data suggest that the production of TGF $\beta$ is one of the factors that differ between patients with MCI and with overt AD. In the cytokine network, TGF $\beta$ acts as an anti-inflammatory cytokine, inhibiting the production of the proinflammatory cytokines such as TNF $\alpha$, ILl, and IL6 by astrocytes, ${ }^{32}{ }^{33}$ and suppressing the activation and proliferation of microglia. ${ }^{33}$ The production of TGF $\beta$ is regulated by other cytokines including TNF $\alpha .{ }^{34}$ In patients with MCI, the increased levels of TNF $\alpha$ may trigger the production of TGF $\beta$ by a negative feed back mechanism to counteract the proinflammatory effects of TNF $\alpha$. However, TGF $\beta$ has other properties of interest in the case of $\mathrm{AD}$, for example, it is known to promote amyloidogenesis in experimental models of AD indicating that it may be a risk factor for developing $\mathrm{AD} .{ }^{35}$ In addition, TGF $\beta$ is also implicated in angiogenesis. This cytokine has been demonstrated to induce the production of vascular endothelial growth factor (VEGF), ${ }^{36}$ one of the most potent angiogenic growth factors. TGF $\beta$ has also been demonstrated to be activated during hypoxia $^{38}{ }^{39}$ and it has been speculated that hypoxia triggered TGF $\beta$ activation may be a prerequisite for the upregulation of VEGF and stimulation of angiogenesis. ${ }^{39}$ Interestingly, the nun study has shown that patients with both vascular pathology and $\mathrm{AD}$ pathology displayed severe dementia. ${ }^{40}$ Thus, we speculate that, in patients with MCI who convert to $\mathrm{AD}$, a shift occurs in the production of TGF $\beta$, from inhibition to overproduction and that this event could be the second prerequisite to trigger AD pathology. One of the limitations of this study was that the follow up period was comparativly short and analyses of cytokines in CSF were not performed at the follow up examination. Further prospective studies are needed to evaluate the kinetics of cytokine production in patients with mild cognitive deficit at risk to develop dementia.

Increased levels of CSF-tau, reflecting the neuronal degeneration have previously been found in patients with $\mathrm{AD}^{29}{ }^{41} 42$ Similarly, decreased levels of CSF-A $\beta 42$, the main component of SP, has been found in patients with $\mathrm{AD}^{21}{ }^{22}$ possibly reflecting an increased consumption of this protein caused by the formation of SP. This study suggests that increased neuronal degeneration is evident also in patients with mild cognitive deficit risking to develop $\mathrm{AD}$ and that increased levels of tau protein in CSF is an early marker of $\mathrm{AD}$. In addition, the decrease of $\mathrm{A} \beta 42$ was more prominent in MCI patients developing $\mathrm{AD}$ than in MCI patients who did not, suggesting that $\mathrm{A} \beta 42$ is early involved in the pathophysiology of AD. Interestingly, the levels of these proteins were correlated to the levels of IL1 $\beta$ in patients developing $\mathrm{AD}$ in the follow up but not in the remaining patients. In this respect, it should be noted that immunoreactivity for ILl $\beta$ has been detected in AD brains. ${ }^{7}$ ILl $\beta$ has also been demonstrated to increase the synthesis of APP mRNA in human endothelial cells, ${ }^{10}$ suggesting a direct role for this cytokine in the formation of SP. In addition, ILl $\beta$ has been demonstrated to induce neuronal degeneration in animal models ${ }^{43}$ and to mediate $\mathrm{A} \beta$ induced inflammatory reaction. ${ }^{44}$ Thus, the correlation between tau, a marker for neurodegeneration, $A \beta$, involved in the formation of SP and ILl $\beta$ in patients with MCD who are soon to develop AD suggests that ILl $\beta$ is an early initiator/mediator of this condition.

In conclusion, our results demonstrate increased production of the proinflammatory cytokine, TNF $\alpha$ and decreased production of the anti-inflammatory cytokine TGF $\beta$ in patients with $\mathrm{MCI}$ at risk to develop $\mathrm{AD}$, as well as correlation between ILl $\beta$ and markers for neurodegeneration and amyloidogenesis, suggesting a propensity towards inflammation in these patients and indicating that CNS inflammation precedes development of AD.

\section{ACKNOWLEDGEMENT}

We thank Mrs Margareta Verdrengh for excellent technical assistance.

\section{Authors' affiliations}

E Tarkowski, A Tarkowski, Department of Rheumatology, University of

Göteborg, Göteborg, Sweden

E Tarkowski, Department of Geriatrics, University of Göteborg

K Blennow, Department of Clinical Neurosciences (Section of

Neurochemistry), University of Göteborg and Department of Clinical

Chemistry, University of Göteborg

N Andreasen, Karolinska Institut, NEUROTEC, Department of Clinical Geriatrics, Stockholm, Sweden

Funding: this study was supported by grants from the Göteborg Medical Society, University of Göteborg, The Swedish Association against

Rheumatism, the King Gustaf V's 80-year Foundation, Stroke Foundation, Gamla Tjänarinnor Foundation, John and Brit Wennerströms Foundation, Rune and Ulla Amlöv Foundation, Konrad and Helfrid Johanssons Foundation, Loo and Hans Ostermans Foundation, Clas Groschinsky Foundation, Wilhelm and Martina Lundgrens Foundation, Alzheimer's Foundation, the Swedish Association of Neurologically Disabled, the Swedish Heart-Lung Foundation, the Swedish Society of Medicine, and the Swedish Medical Research Council (grants numbers 11560 and $12103)$.

Competing interests: none declared.

\section{REFERENCES}

1 Masters CL, Simms G, Weinman NA, et al. Amyloid plaque core protein in Alzheimer disease and Down syndrome. Proc Natl Acad Sci 1985;82:4245-9.

2 Banati RB, Beyreuter K. Alzheimer's disease. In: Kettenman H, Ransom BR, eds. Neuroglia. New York: Oxford University Press, 1995: 1027-43.

3 McGeer PL, Akiyama H, ltagaki $\mathrm{S}$, et al. Immune system response in Alzheimer's disease. Can J Neurol Sci 1989;16:516-27.

4 McGeer PL, Itagaki S, Tago H, et al. Reactive microglia in patients with senile dementia of Alzheimer type are positive for the histocompatibility glycoprotein HLA-DR. Neurosci Lett 1987;79: 195-200.

5 St Pierre BA, Merill JE, Dopp JM. Effects of cytokines on the CNS cells: glia. In: Ransohoff RM, Benveniste EN, eds. Cytokines and the CNS. Boca Raton, FL: CRC Press, 1996:151-68

6 Baver J, Ganter U, Strauss S, et al. The participation of interleukin-6 in the pathogenesis of Alzheimer's disease. 45th forum in Immunology. Res Immunol 1992;143:650-7.

7 Griffin WST, Stanley LC, Ling C, et al. Brain interleukin 1 and S-100 immunoreactivity are elevated in Down syndrome and Alzheimer disease. Proc Natl Acad Sci USA 1989;86:761 1-15

8 Dickson DW, Lee SC, Mattiace LA, et al. Microglia and cytokines in neurological disease, with special reference to AIDS and Alzheimer's disease. Glia 1993;7:75-83.

9 Vandenabeele P, Fiers W. Is amyloidogenesis during Alzheimer's disease due to an IL-1-/IL-6-mediated "acute phase response" in the brain? Immunol Today 1991;12:217-19.

10 Goldgaber D, Harris HW, Hla T, et al. Interleukin 1 regulates synthesis of amyloid $\beta$-protein precursor mRNA in human endothelial cells. Proc Natl Acad Sci USA 1989:86:7606-10.

11 Licinio J, Wong M, Gold PW. Localization of interleukin-1 receptor antagonist mRNA in rat brain. Endocrinology 1991;129:562-4.

12 Dinarello CA, Thompson RC. Blocking IL-1: interleukin 1 receptor antagonist in vivo and in vitro. Immunol Today 1991;12:404-10.

13 Relton JK, Rothwell NJ. Interleukin-1 receptor antagonist inhibits ischaemic and excitotoxic neuronal damage in the rat. Brain Res Bull 1992;29:243-6.

14 Cheng B, Christakos S, Mattson MP. Tumor necrosis factors protect neurons against metabolic-excitotoxic insults and promote maintenance of calcium homeostasis. Neuron 1994:12:139-53.

15 Schwartz M, Solomon A, Lavie V, et al. Tumor necrosis factor facilitates regeneration of injured central nervous system axons. Brain Res $1991 ; 545: 334-8$

16 Barger SW, Hörster D, Furukawa K, et al. Tumor necrosis factors $\alpha$ and $\beta$ protect neurons against amyloid $\beta$-peptide toxicity: Evidence for involvement of a KB-binding factor and attenuation of peroxide and $\mathrm{Ca}^{2+}$ accumulation. Proc Natl Acad Sci USA 1995;92:9328-32.

17 Tarkowski E, Wallin A, Blennow K, et al. Local production of TNF- $\alpha$, a potent neuroprotective agent, in Alzheimer disease and vascular dementia. J Clin Immunol 1999;19:223-30.

18 Tarkowski E, Liljeroth A-M, Nilsson $\AA$, et al. TNF gene polymorphism and its relation to intracerebral production of TNF- $\alpha$ and $-\beta$ in $A D$. Neurology 2000;54:2077-81.

19 Tarkowski E, Wallin A, Regland B, et al. Local and systemic cytokine release in patients with Alzheimer disease and vascular dementia. Acta Neurol Scan 2001;103:166-74.

20 Tarkowski E, Issa R, Siögren M, et al. Increased intrathecal levels of the angiogenic factors VEGF and TGF- $\beta$ in Alzheimer's disease and vascular dementia. Neurobiol Aging 2002;23:237-43.

21 Andreasen N, Hesse C, Davidsson P, et al. Cerebrospinal fluid $\beta$-amyloid ${ }_{(1-42)}$ in Alzheimer's disease: differences between early- and late-onset $A D$ and stability during the course of disease. Arch Neurol 1999;56:673-80. 
22 Andreasen N, Blennow K, Siödin C, et al. Prevalens and Incidens of clinically diagnosed memory impairments in a geographically defined general population in Sweden. The Piteå Dementia project. Neuroepidemiology1999;18:144-55.

23 Andreasen N, Minthon L, Vanmechelen E, et al. Cerebrospinal fluid tau and $A \beta 42$ as predictors of development of Alzheimer's disease in patients with mild cognitive impairment. Neurosci Lett 1999;273:5-8.

24 Folstein MF, Folstein SE, Mc Hugh P. "Mini-mental state" A practical method for grading the cognitive state of patients for the clinician. $J$ Psychiatr Res 1975;12:189-98.

25 Petersen RC, Smith GE, Ivnik RJ, et al. Apolipoprotein E, status as a predictor of the development of Alzheimer's disease in memory-impaired individuals. JAMA 1995;273:1274-8.

26 American Psychiatric Association. Diagnostic and statistical manual of mental disorders. 4th edn. Washington, DC: American Psychiatric Association, 1994

27 Wallin A, Blennow K, Scheltens PH. Research criteria for clinical diagnosis of "pure" Alzheimer's disease. Drugs of Today $1994 \cdot 30 \cdot 265-73$.

28 Mc Khann G, Drachman D, Folstein M, et al. Clinical diagnosis of Alzheimer's disease: report of the NINCDS-ADRDA Work Group under the auspices of Department of Health and Human Services Task Force on Alzheimer's Disease. Neurology 1984:34:939-44.

29 Blennow K, Wallin A, Ågren H, et al. Tau protein in cerebrospinal fluid: a biochemical marker for axonal degeneration in Alzheimer's disease? Mol Chem Neuropathol 1995;26:231-45.

30 Vanderstichele H, Blennow K, D'Heuvaert N, et al. Development of a specific diagnostic test for measurement of b-amyloid(1-42) in CSF. In Fisher A, Hanin I, Yoshida M, eds. Progress in Alzheimer's and Parkinson's diseases. New York: Plenum Press, 1998:773-8

31 Akiyama H, Barger S, Barnum S, et al. Inflammation and Alzheimer's disease. Neurobiol Aging 2000;21:383-421.

32 Benveniste EN, Tang LP, Law RM. Differential regulation of astrocyte TNF- $\alpha$ expression by the cytokines TGF- $\beta$, IL-6 and IL-10. Int J Dev Neurosci 1995;13:341-9.
33 Suzumara A Sawada M, Yamamoto $\mathrm{H}$, et al. Transforming growth factor- $\beta$ suppresses activation and proliferation of microglia in vitro. $J$ Immunol 1993;151:2150-8.

34 Tracey KJ. Tumor necrosis factor. In: Remick DG, Friedland JS, eds. Cytokines in health and disease. 2nd edn. NewYork: Marcel Dekker, 1997:223-39.

35 Wyss-Coray T, Masliah E, Mallory M, et al. Amyloidogenic role of cytokine TGF- $\beta 1$ in transgenic mice and in Alzheimer's disease. Nature 1997;389:603-6

36 Thomas KA. Vascular endothelial growth factor, a potent and selective angiogenic agent. J Biol Chem 1996;27:603-6.

37 Koochekpour S, Merzak A, Pilkington GJ. Vascular endothelial growth factor production is stimulated by gangliosides and TGF- $\beta$ isoforms in human glioma cells in vitro. Cancer Letts 1996;102:209-15.

38 Krupinski J, Kumar P, Kumar S, et al. Increased expression of TGF- $\beta 1$ in brain tissue after ischemic stroke in humans. Stroke 1996;27:852-7.

39 Behzadian MA, Wang X-L, Shabrawey M, et al. Effects of hypoxia on glial cell expression of angiogenesis-regulating factors VEGF and TGF- $\beta$. Glia 1998;24:216-25.

40 Snowdon DA, Greiner $\mathrm{LH}$, Mortimer JA, et al. Brain infarction and the clinical expression of Alzheimer's disease. The nun study. JAMA 1997:277:813-17.

41 Andreasen N, Vanmechelen E, Van der Voorde A, et al. Cerebrospinal fluid tau protein as a biochemical marker for Alzheimer's disease: a community based follow-up study. I Neurol Neurosurg Psychiatry 1998;64:298-305

42 Galasko D Chang L, Motter R, et al. High cerebrospinal fluid tau and low amyloid beta 42 levels in the clinical diagnosis of Alzheimer disease and relation to apolipoprotein E genotype. Arch Neurol 1998;55:937-45

43 Holmin S, Mathiesen T. Intracerebral administration of interleukin-1-beta induces neuronal DNA-fragmentation, encephalitis and vasogenic edema. J Neurosurgery 2000:92:108-20.

44 Sutton ET, Thomas T, Bryant MW, et al. Amyloid-beta peptide induced inflammatory reaction is mediated by the cytokines tumor necrosis factor and interleukin-1. J Submicrosc Cytol Pathol 1999;31:313-23.

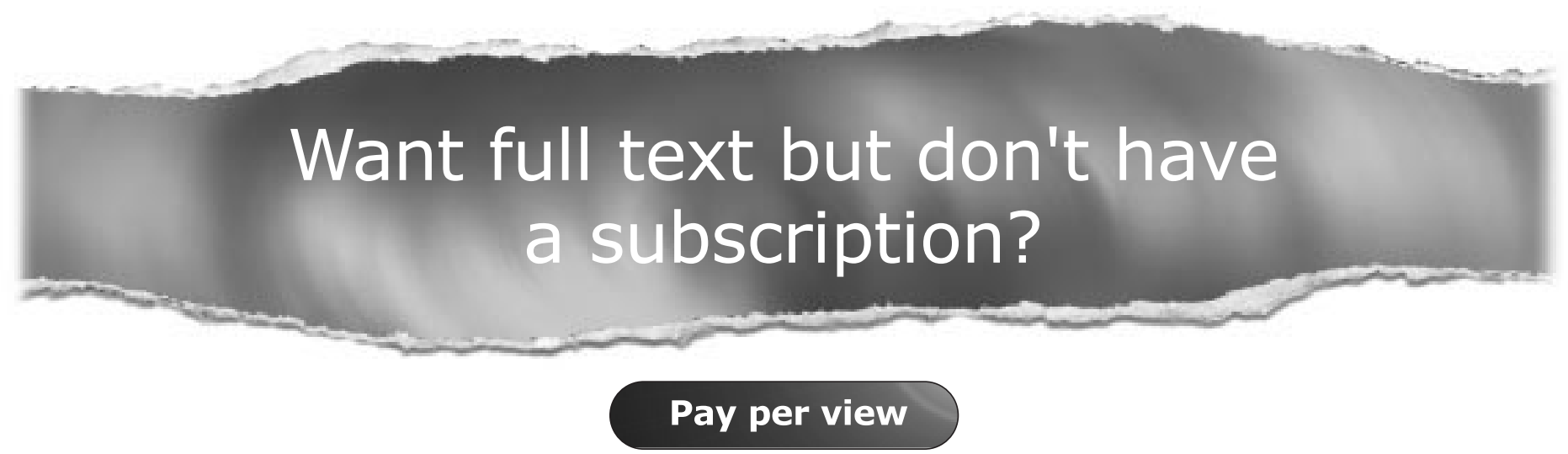

For just \$8 you can purchase the full text of individual articles using our secure online ordering service. You will have access to the full text of the relevant article for 48 hours during which time you may download and print the pdf file for personal use.

\section{www.jnnp.com}

